\title{
Nitric oxide in blastocyst implantation in the rhesus monkey
}

\author{
Jayasree Sengupta, Latika Dhawan, P G L Lalitkumar and D Ghosh \\ Department of Physiology, All India Institute of Medical Sciences, New Delhi, India \\ Correspondence should be addressed to D Ghosh; Email: dghosh@aiims.ac.in
}

\begin{abstract}
Successful blastocyst implantation depends on the interaction between cells of maternal endometrium and conceptus, as well as adequate blood supply to the site of blastocyst implantation. Nitric oxide (NO) generally plays a significant role in the local regulation of vascular physiology in a variety of mammalian tissue systems, however, its role in blastocyst implantation and placentation in the primate is not known. The aim of the present study was to examine: (i) NADH-diaphorase activity and expression of three isoforms of nitric oxide synthase (NOS), namely endothelial NOS (eNOS), inducible NOS (iNOS) and neuronal NOS (nNOS) in pre-implantation stage monkey embryos, morula $(n=4)$ and blastocyst $(n=10)$, as well as, in different compartments of conceptus and maternal endometrium at primary implantation sites during lacunar $(n=6)$ and villous $(n=9)$ stages of placentation in the rhesus monkey, and (ii) the potential anti-nidatory effect of vaginal administration of NOS inhibitor during the peri-implantation period of conception cycles in rhesus monkeys. Pre-implantation stage blastocysts exhibited marked NADPH-diaphorase activity along with immunopositive iNOS mainly in the inner cell mass. During the lacunar stage, marked eNOS expression was observed in cytotrophoblast cells lining the embryonic cavity. However, cytotrophoblast cells lining villi, forming columns, and constituting anchoring villi expressed all the three isoforms of NOS in villous placenta stage tissue. During the lacunar stage, eNOS and iNOS protein expressions were observed in epithelial and decidual cells of endometrium. As gestation advanced, mRNAs for all three isoforms of NOS were observed to increase in epithelial and decidual cells, however, with no marked change in protein expression. Vaginal administration of a NOS inhibitor ( $\mathrm{N}^{\mathrm{G}}$-nitro-L-arginine methyl ester, $\mathrm{L}-\mathrm{NAME}, 4,6$, and $8 \mathrm{mg} / \mathrm{kg}$ body weight or aminoguanidine, AG, $4 \mathrm{mg} / \mathrm{kg}$ body weight) during days 6 to 12 after ovulation resulted in pregnancy failure in a higher number of animals (L-NAME: 8 confirmed pregnancies in 25 animals; AG: 2 confirmed pregnancies in 8 animals) compared with control animals (5 pregnancies in 7 animals). It appears that NO may play an important role in the establishment of pregnancy in the rhesus monkey.

Reproduction (2005) $130321-332$
\end{abstract}

\section{Introduction}

Nitric oxide (NO) is a multifunctional biomolecule that is produced by the enzyme nitric oxide synthase (NOS) (Moncada et al. 1991, Radomski 1995). There are three distinct isoforms of NOS; endothelial and neuronal types (eNOS and nNOS respectively) are constitutive and calcium-calmodulin dependent, while the third one is inducible NOS (iNOS), which is not dependent on calcium-calmodulin for its enzymatic activity (Berdeaux 1993). NO is involved in a number of physiological processes which include vasodilation, angiogenesis, platelet aggression, leucocyte egression, macrophage activity, immune functions, connective tissue remodeling and smooth muscle activity (Moncada et al. 1991, Radomski 1995, Sooranna et al. 1995). Some of these events occur during the establishment of pregnancy, and the involvement of $\mathrm{NO}$ in mammalian embryogenesis and gestation has been demonstrated in small laboratory animals (Chwalisz et al. 1999, Ota et al. 1999, Purcell et al. 1999, Gagioti et al. 2000, Chen et al. 2001, Novaro et al. 2002). There is also evidence suggesting that human endometrial cells express NOS (Telfer et al. 1995, Tseng et al. 1996, Khorram et al. 1999) and that uterine $\mathrm{NO}$ may be involved during pregnancy in the human (Natuzzi et al. 1993, Yallampalli et al. 1994, Dong et al. 1996, Sladek et al. 1997). NOS has been localized in syncytiotrophoblast cells of term placenta (Conrad et al. 1993, Myatt et al. 1993), and in extravillous trophoblast cells (Martin \& Conrad 2000), as well as, cytotrophoblast cells of the cell column of anchoring villi (Ariel et al. 1998) of the human placenta. However, there is no knowledge about the localization of NOS expression in cells of conceptus and maternal endometrium at the time of blastocyst implantation and initiation of placentation in the human and in the non-human primate. More over, it is not known 
whether inhibition of NOS activity may inhibit the process of establishment of pregnancy in the primate. In the present study, we have examined: (i) the NOS expression in pre-implantation stage rhesus monkey embryos, morula and blastocyst, and (ii) the expression patterns of mRNA and protein of NOS isoforms in different cell types of maternal endometrium and conceptus at the primary implantation site of the rhesus monkey. Furthermore, we have examined the hypothesis that $\mathrm{NO}$ is important for the establishment of pregnancy with the use of NOS inhibitor, e.g. $\mathrm{N}^{\mathrm{G}}$-nitro-L-arginine methyl ester (L-NAME), or aminoguanidine (AG) (Joly et al. 1994) administered intra-vaginally during peri-implantation stage of potential conception cycles in rhesus monkeys.

\section{Materials and Methods}

\section{Animal}

Sexually mature, healthy and proven fertile female $(4.5-5.8 \mathrm{~kg})$ and male $(6.5-8.5 \mathrm{~kg})$ rhesus monkeys (Macaca mulatta) were used in this study. Monkeys were individually housed in cages having access to natural light and fed with standard pellet diet supplemented with fresh fruits, soaked gram, peanut, and water ad libitum. The study was carried out at the Primate Research Facility (PRF) of the All India Institute of Medical Sciences (AIIMS), New Delhi, India. The experiment was performed with the approval of the Ethics Committee for the Use of NonHuman Primates in Biomedical Research of the AIIMS.

\section{Blood sampling and estimation of hormone levels}

Every morning blood samples were collected by venipuncture from cycle day 8 onwards until the day of tissue collection or embryo recovery and were used to determine the peripheral serum levels of oestrogen, progesterone, and monkey chorionic gonadotropin (mCG), as described previously (Ghosh et al. 1997). Serum samples were kept at $-20^{\circ} \mathrm{C}$ until hormone assays were performed.

\section{Pre-implantation stage embryo}

The methodological details for pre-implantation stage embryo recovery are given elsewhere (Ghosh et al. 1994). Briefly, female animals $(n=18)$ showing at least two consecutive cycles of normal length (26-32 days) were used in this part of the study, and were cohabited with males between days 8 to 16 of the ovulatory cycles. Success in insemination was assessed by daily microscopic examination of vaginal smear during the mating period. On day 6 after ovulation, as estimated from serum oestradiol-17 $\beta$ and progesterone profiles, monkeys were laparotomized under ketamine hydrochloride $(12 \mathrm{mg} / \mathrm{kg}$ body weight, i.m.; Parke-Davis, Mumbai, India) anaesthesia, and after checking the ovulation point the entire reproductive tract was flushed with Hank's balanced salt solution $(\mathrm{pH} 7.2)$ to retrieve embryos as described previously (Ghosh \&
Sengupta 1991, Ghosh et al. 1994). Fourteen animals yielded pre-implantation stage embryos: four morulae, seven zona-encased blastocysts and three zona-free blastocysts. No embryo could be recovered from four animals despite clear ovulation and good insemination. Six embryos (two morulae, three zonal blastocysts and one zona-free blastocyst) were fixed in $4 \%$ paraformaldehyde in phosphate buffer ( $\mathrm{pH} 7.4)$, dehydrated in a series of graded ethanol and embedded in London Resin White (EM Sciences, Washington, PA, USA) according to the protocol given by the manufacturer (Ghosh et al. 2000a). One micrometre sections were collected on glass slides and used for immunohistochemistry as described below. The other eight pre-implantation stage embryos were processed for NADPH-diaphorase reaction in vitro as described below.

\section{Tissue collection and analysis of implantation sites}

The methodological details are given elsewhere (Ghosh et al. 1999). Briefly, menstrual cycles were monitored by daily examination of vaginal swabs. Female monkeys $(n=20)$ showing at least two consecutive cycles of normal length (26-32 days) were used in this part of the study, and were cohabited with males from days $8-16$ of ovulatory cycles. Success in insemination was assessed by daily microscopic examination of vaginal smear during the mating period. On estimated day of gestation (days 12 to 17), monkeys were laparotomized under ketamine anaesthesia as described above, and subjected to in situ perfusion fixation with $4 \%$ neutral-buffered paraformaldehyde. Uteri were then removed by hysterectomy. Each uterine specimen was quickly washed in cold phosphatebuffered saline (PBS) to remove adherent blood and was excised to expose the primary implantation site which was then placed in cold $4 \%$ paraformaldehyde fixative for $24 \mathrm{~h}$ at $4{ }^{\circ} \mathrm{C}$ and then further processed through graded dehydration, clearing and embedding in paraffin (Ghosh et al. 1999). Based on light microscopic examination of haematoxylin stained paraffin sections, the implantation stages for each sample were documented based on earlier observations (Ghosh et al. 1999, 2000b, 2004, Dhara et al. 2001, Sengupta et al. 2003) and 15 samples were selected for further study. Implantation sites and associated fetal and maternal compartments were analysed using the zonation description given by Enders \& King (1991). Immunohistochemical localization for cytokeratin, vimentin, and von Willebrand factor (vWF) was performed in successive sections to distinguish trophoblast cells, mesenchymal cells, stromal decidual cells and endothelial cells, respectively at implantation sites (Ghosh et al. 1999, 2000b, 2004, Dhara et al. 2001, Sengupta et al. 2003).

\section{NADPH-diaphorase histochemistry}

Eight embryos were processed for NADPH-diaphorase histochemistry according to the procedure described by 
Nishikimi et al. (2001). Five recovered embryos were washed in PBS $(\mathrm{pH} 7.2)$ contining $0.2 \%$ Triton- $\mathrm{X} 100$ and subjected to incubation for $1 \mathrm{~h}$ at $37^{\circ} \mathrm{C}$ in Tris- $\mathrm{HCl}$ $(0.1 \mathrm{mmol} / \mathrm{l}, \quad \mathrm{pH} \quad 7.2)$ buffer containing $\beta$-NADPH $(1 \mathrm{mmol} / \mathrm{l})$ and nitroblue tetrazolium $(0.2 \mathrm{mmol} / \mathrm{l})$. Three embryos were used as the control in which the incubation was performed as above but no $\beta$-NADPH was added in the incubation medium. The embryos were washed quickly in buffer containing $0.2 \%$ Triton-X100 and mounted onto slides for visualization and documentation. All the chemicals were obtained from Sigma Chemical Co. (St Louis, MO, USA).

\section{Immunohistochemistry}

Immunohistochemistry staining was performed with buffered, paraformaldehyde-fixed, deparaffinised tissue sections $(5 \mu \mathrm{m})$ and London Resin White embedded embryo sections $(1 \mu \mathrm{m})$ using the method described previously (Ghosh et al. 1999, 2000a, 2000b, 2004, Dhara et al. 2001, Sengupta et al. 2003). Immunohistochemistry for all the three isoforms of NOS - eNOS, nNOS, and iNOS were performed using antibodies (Cayman Chemical Co., $\mathrm{MI}$, USA) raised in rabbits against recombinant human antigens. Dilutions of stocks of antibodies for immunohistochemistry were optimized. Final visualization was achieved using the $A B C$ peroxidase kits (Vector Laboratories, Burlingame, CA, USA) and freshly prepared diaminobenzidine hydrochloride (Sigma) and hydrogen peroxide. For $1 \mu \mathrm{m}$ embryo sections, DAB enhancing solution (Vector Laboratories) was used to enhance the signal for better assessment and analysis. Specificity of the antibody binding and visualization were assessed by omitting primary antibodies, replacing primary antibody with unrelated immunoglobulins from the same species and other species, omitting secondary antibodies, and replacing labelled secondary antibody with unrelated labelled immunoglobulins from the same species and other species. Labelled and unlabelled immunoglobulins, nonimmune sera and other supplies for immunohistochemistry were purchased from Vector Laboratories. Additional control assessment using preadsorbed immunoglobulins with recombinant control peptides (Cayman Chemical Co., MI, USA) was performed.

\section{In situ hybridization}

The in situ hybridization (ISH) protocol used in the present study was based on the method described earlier (Ghosh et al. 2000b) and using the antisense and sense probe templates for eNOS (271 bp), nNOS (330 bp), and iNOS (371 bp) from Cayman Chemical Co. Briefly, $5 \mu \mathrm{m}$ paraffin sections were dewaxed in xylene and hydrated through graded ethanol to PBS ( $\mathrm{pH}$ 7.4). Proteinase $\mathrm{K}(10 \mu \mathrm{g} / \mathrm{ml}$ in PBS; Amresco, Solon, OH, USA) digestion was performed at room temperature for $30 \mathrm{~min}$. Following washes in PBS, sections were refixed in freshly prepared $4 \%$ neutral buffered paraformaldehyde at $4{ }^{\circ} \mathrm{C}$ for $20 \mathrm{~min}$, and then were washed in PBS. Finally, dehydration was done with graded ethanol and air-dried.

On the other hand, single stranded sense and antisense RNA probes were transcribed from linearised templates using DIG RNA labelling kit (Boehringer-Mannheim, Mannheim, Germany) and using the protocol described by the manufacturer. Riboprobes $(\sim 5 \mathrm{ng} / \mu \mathrm{l})$ were mixed with $40 \mu$ l of hybridization mixture containing deionized formamide $(50 \%, v / v), 50 \%(w / v)$ dextran sulphate $(20 \%, v / v)$, 100X Denhardt mixture $(1 \%, \mathrm{v} / \mathrm{v})$, Tris $(1 \mathrm{M}, \mathrm{pH} 8.0)$, sodium chloride, EDTA and yeast t-RNA ( $5 \mathrm{mg} \%$ ) and were denatured at $80^{\circ} \mathrm{C}$. The chemicals for hybridization were obtained from Sigma and Amresco (Solon, OH, USA). The riboprobes were applied to the pretreated and dried section, and hybridization was carried out for $18 \mathrm{~h}$ at $47^{\circ} \mathrm{C}$ in a sealed humidified chamber equilibriated with $50 \%$ formamide and $0.3 \mathrm{M} \mathrm{NaCl}$. Post hybridization stringency washes were done in $2 \times$ SSC and then $0.1 \times$ SSC at $47^{\circ} \mathrm{C}$. After washing in $2 \times \mathrm{SSC}$ at $37^{\circ} \mathrm{C}$, the hybridized probes were detected by using DIG nucleic acid detection kit (Boehringer Mannheim, Mannheim, Germany) and using the protocol supplied by the manufacturer.

\section{Microscopic assessment}

At least three sections of each primary implantation site for each immunochemical staining and in situ hybridization were examined. Samples examined belong to either lacuna stage $(n=6)$ or villous placenta stage $(n=9)$. For assessment of staining in cells at implantation sites, semi-quantitative subjective scoring was done in a blinded manner by three investigators using a 4 -scale system: $0=$ nil; $1=$ weak; 2 = moderate; 3 = strong (Ghosh et al. 1999, 2000b, 2004, Sengupta et al. 2003). It was assumed that these measurements reflect the concentrations of the experimental probes in different endometrial compartments. Immunohistochemitry and NADPH-diaphorase histochemistry of embryo samples were assessed subjectively.

\section{Treatment groups}

Female rhesus monkeys $(n=45)$ showing at least two consecutive cycles of normal length (26-32 days) were used in this part of the study and were randomly assigned to five groups, nine animals in each group. Female animals were cohabited with males from days $8-16$ of their ovulatory cycles. Success in insemination was assessed by daily microscopic examination of vaginal smear during the mating period. On estimated day 6 after ovulation seven animals belonging to group 1 (control) were vaginally inserted with tampons (Tampex, Tambrands, Palmer, MA, USA) bearing a dialysis tube containing PBS $(\mathrm{pH}$ $7.4)$, while nine animals in groups two $(4 \mathrm{mg} / \mathrm{kg}$ body weight) and three $(6 \mathrm{mg} / \mathrm{kg}$ body weight) and seven animals in group four ( $8 \mathrm{mg} / \mathrm{kg}$ body weight) were vaginally inserted with tampons containing $N^{G}$-nitro-L-arginine methyl ester (L-NAME, Sigma), and eight animals in group 
five ( $4 \mathrm{mg} / \mathrm{kg}$ body weight) with aminoguanidine hydrochloride (AG, Sigma), on post ovulation day 6 under light ketamine anaesthesia. The minimal amount of $4 \mathrm{mg}$ NOS inhibitor per animal was arbitrarily adjusted using interspecies allometric scaling considering both allometric coefficient and exponent 0.9, and based on available human and mouse data for L-NAME from the literature (Chen et al. 2001, Mordenti 1986, Cotter et al. 2003, Morgan et al. 2003). Five animals did not show ovulation and were removed from the study. The description of a typical tampon containing the test agent or only PBS has been given earlier (Dhawan et al. 2000). Typically, a $3.0 \mathrm{~cm} \times$ $1.2 \mathrm{~cm}$ tampon with $1.5 \mathrm{~cm}$ thread lead at the bottom was wrapped with a dialysis tube (length, $4.0 \mathrm{~cm}$; diameter, $66 \mathrm{~mm} ; 12000 \mathrm{kD}$ cut-off) filled with buffer either alone or containing test agent. The tampons were removed on post ovulation day 12 of the treatment cycle under light ketamine anaesthesia. Pregnancy establishment was assessed from serum levels of oestrogen and progesterone, as well as, detection of mCG in circulation followed by uterine palpation as described earlier (Ghosh \& Sengupta 1993, Ghosh et al. 1994, 1997). Pregnancy outcome was analysed using Fisher's exact ratio test, and area under the curve (AUC) for hormone levels during the days of treatment (days 6 to 12 after ovulation) for individual females was compared using ANOVA (Zar 1999)

\section{Results}

\section{NOS in pre-implantation stage embryos}

As shown in Fig. 1, pre-implantation stage monkey blastocysts showed marked NADPH-diaphorase activity, and expressed immunopositive iNOS, while morula stage embryos showed very little diaphorase activity and no immunopositive iNOS. Both NADPH-diaphorase activity and NOS immunopositivity were observed predominantly in the inner cell mass. However, no immunopositivity for eNOS and nNOS was seen in morulae or blastocysts.

\section{NOS distribution at primary implantation site}

Tables 1 and 2 show the median scores with ranges of immunohistochemical and in situ hybridization staining for eNOS, iNOS and nNOS in different compartments of conceptus and maternal endometrium at primary implantation sites during lacunar and villous placenta stages of implantation in the rhesus monkey. Fig. 2 shows representative microphotographs of NOS transcripts and proteins as detected by in situ hybridization and immunohistochemistry, respectively, in different compartments of conceptus and maternal endometrium during the early stages of blastocyst implantation and placentation.

\section{Conceptus}

During the lacunar stage of placentation, eNOS and iNOS expressions were observed in cytotrophoblast cells lining the embryonic cavity (Table 1). The mRNA and protein expressions for all three isoforms of NOS were observed in the large trophoblast cells within the chorionic plate. As gestation advanced, cytotrophoblast cells lining villi, within cell columns, as well as in anchoring villi began expressing all the three isoforms of NOS with eNOS being the dominant isoform, while syncytiotrophoblast cells expressed NOS only marginally (Table 2; Fig. 2). Villous stromal cells showed expression of all the three isoforms of NOS.

\section{Maternal endometrium}

As shown in Table 1, during the lacunar stage of placentation, epithelial cells including plaque cells and decidual cells in the maternal endometrium at the primary implantation site generally expressed eNOS and iNOS. As gestation advanced, mRNAs for all three isoforms of NOS increased in epithelial and decidual cells, with no marked change in their protein expression profiles (Tables 1 and 2). The proteins and mRNAs for all three isoforms of NOS were generally very low in endothelial cells of maternal endometrial vasculature at the primary implantation site during both stages of placentation (Tables 1 and 2).

\section{Pregnancy outcome following administration of NOS inhibitors}

Table 3 shows the effect of vaginal administration of vehicle (group 1), L-NAME (groups 2-4) and AG (group 5) on pregnancy outcome in mated, ovulatory cycles of rhesus monkeys. In the control group (group 1), five out of seven animals $(71 \%)$ became pregnant as revealed from steroid hormonal profiles and mCG in circulation. Pregnancy in two animals (C6 and C7) in this group (group 1, control) was allowed to continue, while pregnancy in three animals (C1, C2 and C3) in this group was terminated by the removal of implantation sites between cycle days 27 to 29. Pregnancy in group 2 was confirmed in two $(22 \%)$ out of nine animals who were exposed to vaginal L-NAME (4 mg/kg body weight) during days 6 to 12 after ovulation, while there were four $(44 \%)$ confirmed pregnancies out of nine animals in group 3 receiving vaginal L-NAME, $6 \mathrm{mg} / \mathrm{kg}$ body weight, and two (29\%) confirmed pregnancies from seven animals in group 4 treated with vaginal L-NAME, $8 \mathrm{mg} / \mathrm{kg}$ body weight. On the other hand, two $(25 \%)$ out of eight animals were pregnant in group 5 following treatment with AG during days 6 to 12 after ovulation. One animal from group $4\left(\mathrm{~L}_{8} 1\right)$ and one animal from group 5 (AG5) could not maintain their pregnancies and aborted on 47 and 19 days of gestation, respectively. Finally, twelve animals from all groups gave twelve normal babies (Table 3).

Despite an apparent tendency of inhibition in pregnancy establishment in L-NAME or AG treated animals as compared with control group animals, Fisher's exact probability test failed to detect any significant decrease in the pregnancy outcome in any group of animals treated with 

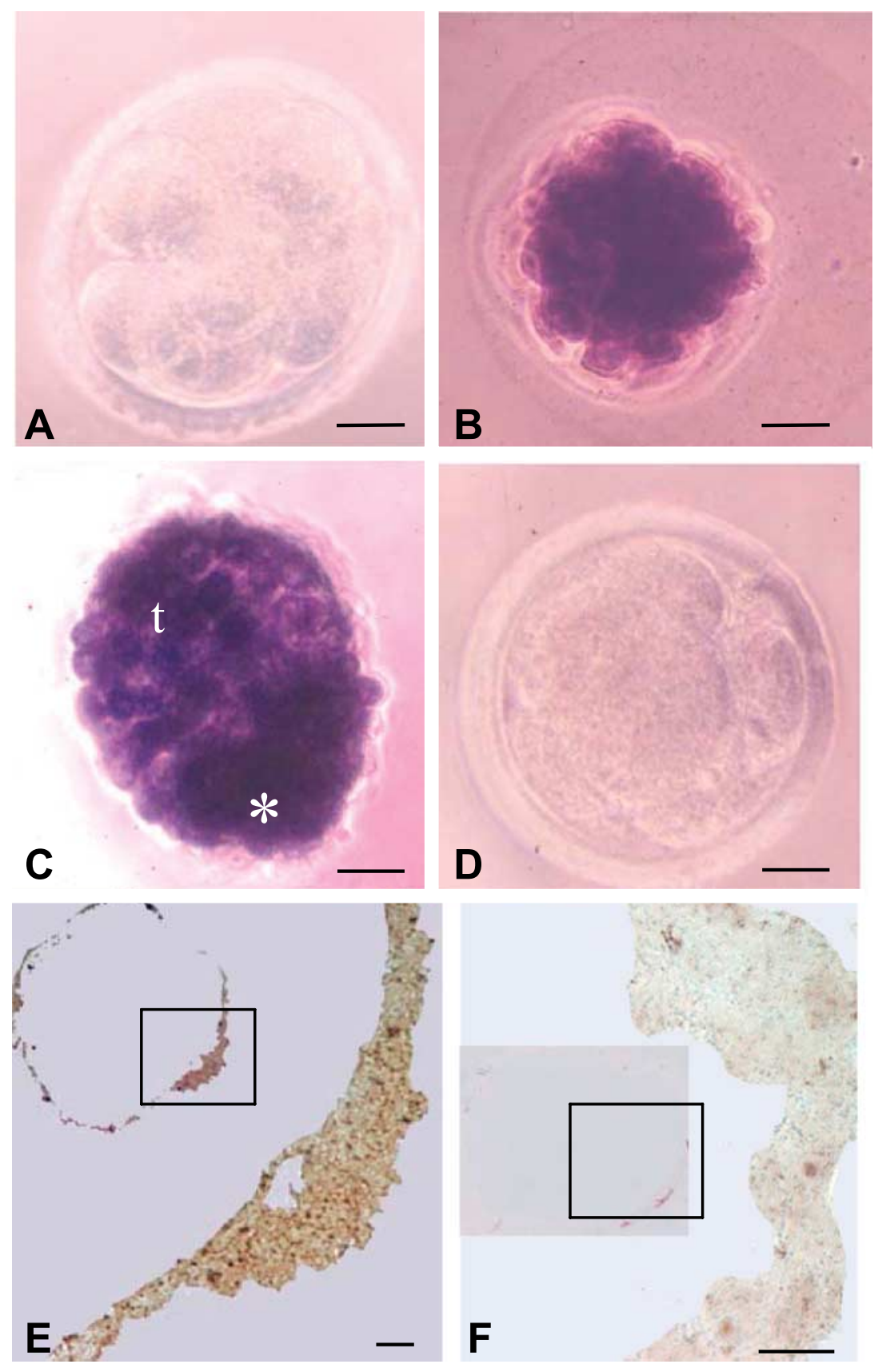

Figure 1 Pre-implantation stage monkey embryos showing NADPH-diaphorase activity (A-D). Enzyme activity detected from formazan grains was low in morula $(A)$, higher in zona-encased blastocyst (B), and maximum in cells of the inner cell mass $(*)$ and trophoblast cells ( $\mathrm{t}$ ) of zona-free blastocyst (C), and very low in an early blastocyst in which $\beta-\mathrm{NADPH}$ was omitted (control) from the incubation medium (D). Immunohistochemical localization of iNOS in $1 \mu \mathrm{m}$ section of zona-free blastocyst was found mainly in cells of the inner cell mass (E). An adjacent section of the same blastocyst incubated in medium without primary antibody for iNOS showed no positive immunostaining (F). Bars $=20 \mu \mathrm{m}(A-D), 5 \mu \mathrm{m}(\mathrm{E}, \mathrm{F})$.
NOS inhibitor as compared with group 1. Analysis of the AUC during days 6 to 12 after ovulation failed to reveal any significant change in the serum levels of oestradiol and progesterone between animals treated with vehicle and animals treated with inhibitor of NOS (either L-NAME or AG), as well as, between animals treated with L-NAME and animals treated with AG.

\section{Discussion}

In the present study, marked NADH-diaphorase activity and iNOS protein were observed in the inner cell mass of implantation stage monkey blastocysts. There is no comparable study in any primate species in the literature, however, similar observations have been reported for preimplantation stage rodent embryos (Nishikimi et al. 2001). While immunoprecipitation of a target protein essentially reveals its presence, but not its activity, and NADH-diaphorase activity per se is not sacrosanct of NOS activity in pre-implantation stage embryos, their marked concordance tends to substantiate the likelihood of NOS activity (Lopez \& Gonzalez 2002). Although the physiological significance of this observation is not known, it is likely that NOS is involved in embryo development. There is 
Table 1 Endothelial nitric oxide sysnthase (eNos), neuronal NOS (nNOS) and inducible NOS (iNOS) in conceptus and endometrium at the primary implantation site $(n=6)$ during the lacuna stage of placentation. Values are given as median scores with ranges in parentheses.

\begin{tabular}{|c|c|c|c|c|c|c|}
\hline \multirow[b]{2}{*}{ Cell type } & \multicolumn{2}{|c|}{ eNOS } & \multicolumn{2}{|c|}{ nNOS } & \multicolumn{2}{|c|}{ iNOS } \\
\hline & $\mathrm{IHC}$ & ISH & $\mathrm{IHC}$ & ISH & $\mathrm{IHC}$ & $\mathrm{ISH}$ \\
\hline \multicolumn{7}{|l|}{ Conceptus } \\
\hline Chorion & $1(0-2)$ & $0(0-2) 1$ & $(0-1)$ & $0(0-1)$ & $1(0-2)$ & $0(0-1)$ \\
\hline Trophoblast cells lining embryo cavity & $2(1-2)$ & $1(1-2)$ & $1(0-2)$ & $0(0-1)$ & $2(1-3)$ & $1(1-2)$ \\
\hline Trophoblast cells lining lacunae & $0(0-1)$ & $1(1-2)$ & $0(0-1)$ & $0(0-1)$ & $0(0-1)$ & $1(0-1)$ \\
\hline Trophoblast cells in chorionic plate & $1(0-2)$ & $2(1-3)$ & $1(0-1)$ & $1(1-2)$ & $1(0-2)$ & $2(1-3)$ \\
\hline \multicolumn{7}{|l|}{ Endometrium } \\
\hline Epithelium & & & & & & \\
\hline Luminal & $2(1-2)$ & $1(0-2)$ & $1(0-2)$ & $0(0-1)$ & $2(0-3)$ & $1(0-2)$ \\
\hline Glandular & $1(0-2)$ & $1(0-2)$ & $1(0-1)$ & $0(0-2)$ & $1(0-1)$ & $1(0-1)$ \\
\hline Plaque & $1(0-2)$ & $2(0-3)$ & $1(0-1)$ & $1(0-2)$ & $2(1-3)$ & $2(1-3)$ \\
\hline Decidual cells & $2(0-3)$ & $1(0-2)$ & $0(0-1)$ & $0(0-2)$ & $2(0-3)$ & $1(1-2)$ \\
\hline Fibroblast cells & $0(0-1)$ & $1(0-1)$ & $0(0-1)$ & $0(0-1)$ & $0(0-2)$ & $1(0-1)$ \\
\hline Endotheliala cells & $0(0-1)$ & $0(0-1)$ & $0(0-1)$ & $0(0-1)$ & $0(0-1)$ & $0(0-1)$ \\
\hline
\end{tabular}

IHC, immunohistochemistry, ISH, in situ hybridization.

evidence that an optimal level of $\mathrm{NO}$ is required for adequate and synchronous development of pre-implantation stage embryos in rodents (Chen et al. 2001, Tranguch et al. 2003). In a pilot study, it has also been observed that NO production in nidating human embryos is positively associated with the growth potential of a developing embryo (Battaglia et al. 2003).

In the present study, we noted that pre-implantation stage monkey blastocysts expressed immunopositive iNOS, while cytotrophoblast cells lining the embryonic cavity, villi, columns and anchoring villi during lacunar and villous stages of placentation in the rhesus monkey expressed both eNOS and iNOS. In the present study, generally a very low to moderately low level of nNOS was detected in most samples, although immunohistometry only gives a relative idea of semi-quantitative assessment at best. In previous reports, nNOS has been localized in trophoblast cells from human term placenta (Sanyal et al. 2000), but not in first trimester placental samples (Al-Hijji et al. 2003). In the present study, all the three isoforms of NOS were observed to a variable extent in extravillous trophoblast cells, non-polarized cytotrophoblast cells of column and villous stromal cells.

In previous studies also, eNOS protein has been located in the extravillous trophoblast cells of the cell columns of anchoring villi in the human placenta (Ariel et al. 1998, Martin \& Conrad 2000). In a recent study, on the other hand, neither eNOS nor iNOS immunopositivity was observed in extravillous cytotrophoblast cells in human placental samples collected between 8 and 19 weeks of gestation (Lyall et al. 1999). The authors suggested that such discrepancy might arise from the technical variations (for example, chemically fixation vs cryo fixation, polyclonal antibody vs monoclonal antibody) in performing immunohistochemistry. While we appreciate this possibility, it is notable that there is a good concordance in semi-quantitative assessments of relative levels between transcripts as detected by in situ hybridization and proteins as detected by immunohistochemistry in our study. Martin \& Conrad (2000) also observed a discernible degree of transcripts for eNOS in extravillous trophobalst cells in human first trimenster placenta samples. In the present study, markedly wide ranges of data were observed for several parameters in primary implantation sites primarily for sample (biological) variation rather than subjective (technical) variation, while uterine myometrial cells, similar to earlier reports in the human (Ramsay et al. 1996, Campa et al. 1998), showed only a low level staining in in situ hybridization and immunohistochemistry (data not shown). It is to be noted, in this connection, that the primary

Figure 2 In situ hybridization and immunohistochemistry of NOS isoforms in cells of conceptus and maternal endometrium in lacunar and villous stages of primary implantation sites collected from rhesus monkeys. Lacunar stage tissues showing eNOS (A), iNOS (B) and nNOS (C) mRNAs in cytotrophoblast cells (arrowhead) lining embryonic cavity and lacunae (l), chorionic plate (p), plaque acini (pl) and in glandular epithelial cells (gl). Immunohistochemical localization of eNOS (D), iNOS (E) and nNOS (F) in syncytiotrophoblast cells (arrows) lining lacunae (I), cytotrophoblast cells (ctb); marked immunostaining for iNOS (E) was found in migratory trophoblast cells (brackets) within the chorionic plate. Immunohistochemical localization of eNOS (G) in cytotrophoblast cells lining villi (arrowhead) and in cell columns (cc), syncytiotrophoblast cells lining cell columns (arrows), migratory extravillous trophoblast cells (brackets) adjoining blood vessel (bv) and gland epithelial cells (gl). In situ hybridization showing mRNAs for iNOS (H) in cytotrophoblast cells of columns (cc) and in decidual cells (d; I) surrounding spiral arterioles $(*)$. In situ hybridization with the sense probe for iNOS did not show any detectable staining (J). No staining was found after immunohistochemistry for eNOS by omitting the primary antibody $(\mathrm{K})$ and for iNOS after incubation in primary antibody immunosorbed with recombinant iNOS $(\mathrm{L})$. Bars $=50 \mu \mathrm{m}(\mathrm{A}-\mathrm{C}, \mathrm{G}-\mathrm{J}), 10 \mu \mathrm{m}(\mathrm{D}-\mathrm{F}, \mathrm{K}, \mathrm{L})$. 


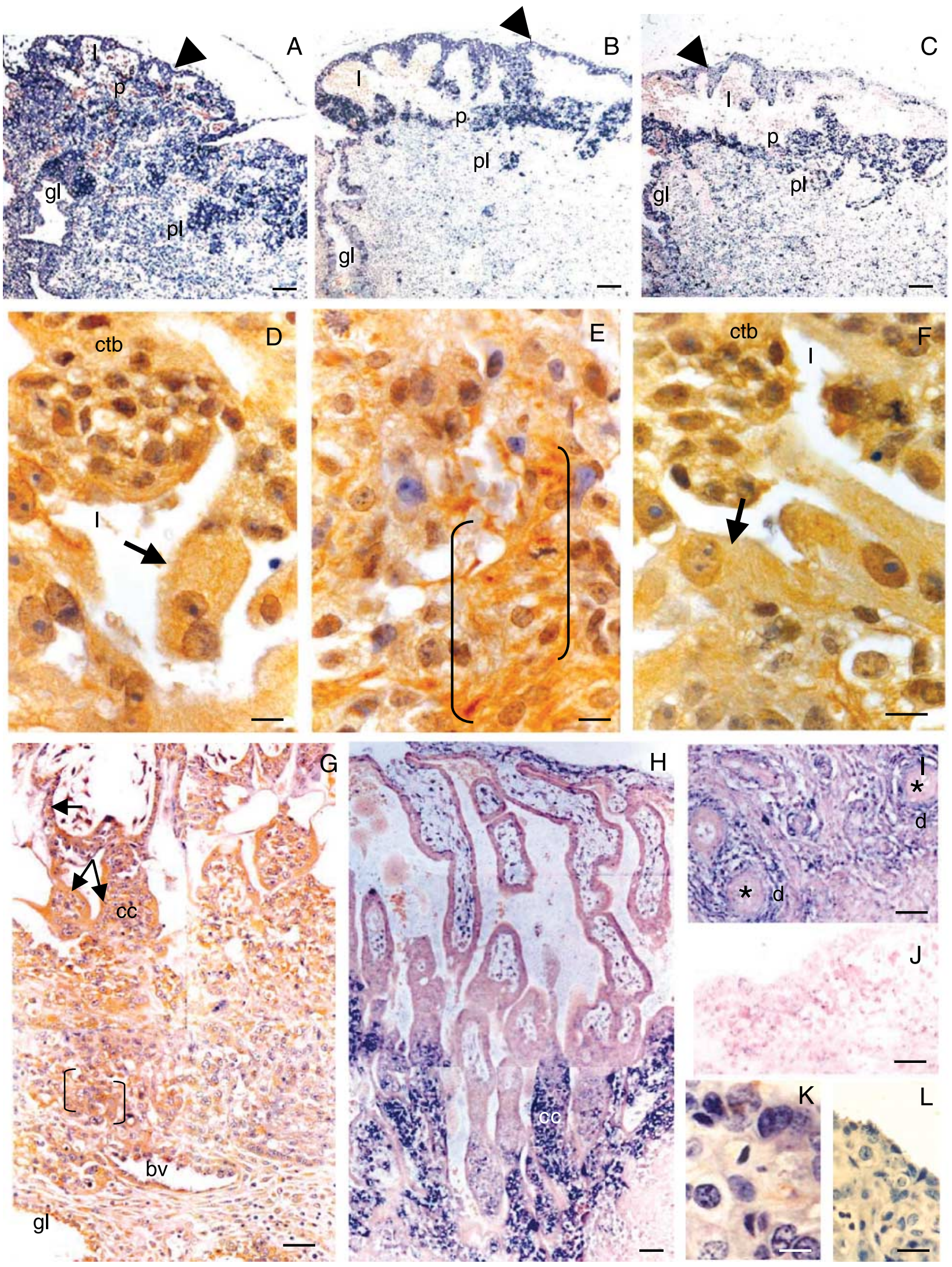


implantation site samples were collected from pregnant rhesus monkeys during very early stages of placentation, between days 12 and 17 of gestation, unlike all previous reported studies in primates including the human.

It is possible that trophoblast derived $\mathrm{NO}$ may play a critical role in preventing platelet adhesion to the trophoblast cell layer as well as inhibiting platelet aggregation within the intervillous space (Radomski et al. 1987). Because NO is a potent vasodilator, it might also contribute to the vasodilation of the maternal systemic circulation at the implantation site. Indeed, it has been earlier reported that $\mathrm{NO}$ produced by periarterial trophoblasts during early pregnancy in the guinea pig contribute to the dilation of the adjacent uteroplacental arteries (Nanaev et al. 1995). NO derived from these cells may also contribute to the local suppression of maternal immunity (Dembinska-Kiec et al. 1991, Belensky et al. 1993).

Interestingly, invasive extravillous trophoblast cells were found to express NOS, and to co-express VEGF and its receptors (Flt-1 and KDR) on days $12-16$ of gestation in the rhesus monkey (Ghosh et al. 2000b, Ghosh \& Sengupta 2004a). VEGF reportedly stimulates the release of NO via phosphorylation of Flt-1 in human first trimester trophoblast cells, and this action is attenuated by L-NAME in a concentration dependent manner, and NO in turn suggestively aids in trophoblast penetration into spiral arterioles (Ahmed et al. 1997) while down-regulating VEGF-stimulated proliferation of trophoblast cells (Cha et al. 2001). Whether NOS activity in extravillous trophoblast cells has any functional association with high expression of interleukin-1 (IL-1) and leukemia inhibitory factor (LIF) during the early stages of placentation (Sengupta et al. 2003) is not known, however, these cytokines are known to influence NO production in a number of tissue systems including endometrium and cultured trophoblast cells (Tamura et al. 1996, Chwalisz et al. 1996, Chwalisz \& Garfield 2000,
Hambartsoumian et al. 2001). NO production by invasive trophoblast cells may induce matrix-degrading proteases, like matrix metalloproteineases 2 and 9, which were reduced by the addition of L-NAME to cells in culture (Novaro et al. 2001). It is likely that trophoblast cells which are epithelial in origin may require $\mathrm{NO}$ for inducing a switch from stationery to locomotory phenotype (Noiri et al. 1996).

Although there is no information available in the literature regarding the expression of NOS in maternal endometrium during the early stages of implantation and placentation in the primates, our observation corroborates well with the available data obtained from studies in the non-gravid premenopausal human uterus (Schmidt et al. 1992, Telfer et al. 1995, 1997, Tseng et al. 1996, Taguchi et al. 2000). In our findings, the expression of NOS by maternal endometrial epithelial cells of luminal surface, glands and plaque acini during early stages of implantation appears intriguing. A role for $\mathrm{NO}$ in the paracrine control of the uterine vascular bed is supported by studies in animals (Kimura et al. 1992, Van Buren et al. 1992). While locally synthesized NO by maternal endometrial plaque epithelium may play an important role in the control of the uterine vascular bed around the primary implantation site (Ziche et al. 1994), it is possible that NO along with other factors from surface and glandular epithelial cells mediate embryotropic action (Hornung et al. 1998, Ghosh \& Sengupta 2004b).

In the present study, we also observed that decidual cells expressed NOS at a low level during lacunar stage, while its expression increased during the villous placental stage of implantation. It is possible that NOS expression in pregnancy associated decidual cells is associated with the process of decidualization. Chwalisz \& Garfield (2000) reported that NO is involved in the process of decidualization, since NOS inhibitors reduced the extent

Table 2 Endothelial nitric oxide synthase (eNOS), neuronal NOS (nNOS) and inducible NOS (iNOS) in conceptus and endometrium at the primary implantation site $(n=9)$ during the villous stage of placentation. Values are given as median scores with ranges in parentheses.

\begin{tabular}{|c|c|c|c|c|c|c|}
\hline \multirow[b]{2}{*}{ Cell type } & \multicolumn{2}{|c|}{ eNOS } & \multicolumn{2}{|c|}{$\mathrm{nNOS}$} & \multicolumn{2}{|c|}{ iNOS } \\
\hline & $\mathrm{IHC}$ & $\mathrm{ISH}$ & IHC & $\mathrm{ISH}$ & IHC & ISH \\
\hline \multicolumn{7}{|l|}{ Conceptus } \\
\hline Cytotrophoblast cells lining villi & $2(1-3)$ & $1(0-2)$ & $0(0-1)$ & $0(0-1)$ & $2(0-3)$ & $0(0-2)$ \\
\hline Syncytiotrophoblast cells lining villi & $1(0-2)$ & $0(0-2)$ & $0(0-1)$ & $0(0-1)$ & $0(0-1)$ & $0(0-1)$ \\
\hline Non-polarised cytotrophoblast cells in columns & $2(0-3)$ & $2(2-3)$ & $1(1-2)$ & $2(1-3)$ & $2(1-3)$ & $2(0-3)$ \\
\hline Syncytiotrophoblast cells lining cytotrophoblast cell column & $0(0-1)$ & $0(0-1)$ & $0(0-1)$ & $1(0-2)$ & $1(0-2)$ & $0(0-1)$ \\
\hline Trophoblast cells of cytotrophoblast shell & $0(0-1)$ & $2(1-3)$ & $0(0-1)$ & $1(1-2)$ & $1(0-2)$ & $2(1-3)$ \\
\hline Extravillous trophoblast cells & $2(1-3)$ & $2(2-3)$ & $1(1-3)$ & $1(0-2)$ & $2(1-3)$ & $2(2-3)$ \\
\hline Extraembryonic mesenchymal cells & $2(1-3)$ & $2(2-3)$ & $1(1-2)$ & $2(0-2)$ & $2(1-3)$ & $2(2-3)$ \\
\hline \multicolumn{7}{|l|}{ Endometrium } \\
\hline \multicolumn{7}{|l|}{ Epithelium } \\
\hline Surface & $2(2-3)$ & $1(0-2)$ & $1(1-3)$ & $1(0-2)$ & $2(1-3)$ & $1(1-2)$ \\
\hline Glandular & $1(1-3)$ & $1(0-1)$ & $0(0-2)$ & $1(0-2)$ & $1(1-2)$ & $1(1-2)$ \\
\hline Plaque & $1(0-1)$ & $3(2-3)$ & $0(0-1)$ & $2(1-3)$ & $2(1-3)$ & $3(1-3)$ \\
\hline Decidual cells & $2(1-3)$ & $2(0-2)$ & $1(0-1)$ & $1(1-3)$ & $2(1-3)$ & $2(1-3)$ \\
\hline Fibroblast cells & $1(1-2)$ & $0(0-1)$ & $0(0-1)$ & $0(0-1)$ & $0(0-1)$ & $0(0-1)$ \\
\hline Endothelial cells & $1(1-2)$ & $0(0-1)$ & $0(0-1)$ & $0(0-0)$ & $0(0-2)$ & $0(0-1)$ \\
\hline
\end{tabular}


Table 3 Pregnancy outcome in monkeys subjected to vaginal administration of vehicle (group 1), $\mathrm{N}^{\mathrm{G}}$-nitro-L-arginine methylester (4 mg/kg, group 2; $6 \mathrm{mg} / \mathrm{kg}$, group 3; $8 \mathrm{mg} / \mathrm{kg}$, group 4$)$ and aminiguanidine $(4 \mathrm{mg} / \mathrm{kg}$, group 5$)$.

\begin{tabular}{|c|c|c|c|c|c|}
\hline \multirow[b]{2}{*}{ Group } & \multirow{2}{*}{$\begin{array}{l}\text { Animal } \\
\text { number }\end{array}$} & \multicolumn{3}{|c|}{$\begin{array}{l}\text { Length of menstrual } \\
\text { cycle }\end{array}$} & \multirow{2}{*}{$\begin{array}{l}\text { Serum mCG detection } \\
\text { (days after ovulation) }\end{array}$} \\
\hline & & Pre- & Treatment & Post- & \\
\hline \multirow[t]{7}{*}{1} & $\mathrm{C} 1$ & 28 & NA & NA &,$+ 12^{1}$ \\
\hline & $\mathrm{C} 2$ & 29 & NA & NA &,$+ 11^{1}$ \\
\hline & C3 & 33 & NA & NA &,$+ 13^{1}$ \\
\hline & C4 & 30 & 29 & 29 & ND \\
\hline & C5 & 29 & 30 & 28 & ND \\
\hline & C6 & 30 & NA & NA &,$+ 13^{2.1}$ \\
\hline & $\mathrm{C} 7$ & 27 & NA & NA &,$+ 12^{3.1}$ \\
\hline \multirow[t]{9}{*}{2} & $\mathrm{~L}_{4} 1$ & 26 & 26 & 24 & ND \\
\hline & $\mathrm{L}_{4} 2$ & 30 & 27 & 29 & ND \\
\hline & $\mathrm{L}_{4} 3$ & 27 & 28 & 27 & ND \\
\hline & $\mathrm{L}_{4} 4$ & 29 & 28 & 37 & ND \\
\hline & $\mathrm{L}_{4} 5$ & 27 & 19 & 61 & ND \\
\hline & $\mathrm{L}_{4} 6$ & 32 & NA & NA &,$+ 15^{2.2}$ \\
\hline & $\mathrm{L}_{4} 7$ & 28 & NA & NA &,$+ 16^{3.2}$ \\
\hline & $\mathrm{L}_{4} 8$ & 31 & 32 & 32 & ND \\
\hline & $\mathrm{L}_{4} 9$ & 26 & 25 & 29 & ND \\
\hline \multirow[t]{9}{*}{3} & $\mathrm{~L}_{6} 1$ & 26 & NA & NA &,$+ 15^{3.3}$ \\
\hline & $\mathrm{L}_{6} 2$ & 30 & NA & NA &,$+ 17^{2.3}$ \\
\hline & $\mathrm{L}_{6} 3$ & 28 & 26 & 29 & ND \\
\hline & $\mathrm{L}_{6} 4$ & 29 & 28 & 27 & ND \\
\hline & $\mathrm{L}_{6} 5$ & 31 & 29 & 26 & ND \\
\hline & $\mathrm{L}_{6} 6$ & 31 & NA & NA &,$+ 18^{2.4}$ \\
\hline & $\mathrm{L}_{6} 7$ & 29 & NA & NA &,$+ 16^{3.4}$ \\
\hline & $\mathrm{L}_{6} 8$ & 28 & 31 & 32 & ND \\
\hline & $\mathrm{L}_{6} 9$ & 27 & 25 & 59 & ND \\
\hline \multirow[t]{7}{*}{4} & $\mathrm{~L}_{8} 1$ & 28 & NA & NA &,$+ 15^{4.1}$ \\
\hline & $\mathrm{L}_{8} 2$ & 28 & 25 & 29 & ND \\
\hline & $\mathrm{L}_{8} 3$ & 28 & 28 & 32 & ND \\
\hline & $\mathrm{L}_{8} 4$ & 30 & 28 & 43 & ND \\
\hline & $\mathrm{L}_{8} 5$ & 27 & 29 & 31 & ND \\
\hline & $\mathrm{L}_{8} 6$ & 29 & NA & NA &,$+ 16^{2.5}$ \\
\hline & $\mathrm{L}_{8} 7$ & 28 & NA & NA &,$+ 16^{3.5}$ \\
\hline \multirow[t]{8}{*}{5} & AG1 & 27 & 24 & 33 & ND \\
\hline & AG2 & 30 & 22 & 29 & ND \\
\hline & AG3 & 26 & 42 & 15 & ND \\
\hline & AG4 & 27 & NA & NA &,$+ 16^{2.6}$ \\
\hline & AG5 & 26 & NA & NA &,$+ 13^{4.2}$ \\
\hline & AG6 & 27 & 55 & 30 & ND \\
\hline & AG7 & 26 & NA & NA &,$+ 19^{3.6}$ \\
\hline & AG8 & 28 & 27 & 27 & ND \\
\hline
\end{tabular}

of decidualization in rats. It is also possible that the expression of NOS by stromal decidual cells may influence the vascular responses during implantation (Rogers et al. 1992, Ziche et al. 1994, Okada et al. 2001). Several cytokines including interleukin-1 (IL-1) and leukemia inhibitory factor (LIF) in implantation stage endometrium (Sengupta et al. 2003) induce an optimal amount of NO production in progesterone dominated endometrium (Franchi et al. 1998, Okada et al. 2001, Novaro et al. 2002); NO, in turn, stimulates the production of matrix metalloproteinases resulting in remodeling of extracellular matrix cooperating the process of implantation (Chwalisz et al. 1996, Tamura et al. 1996). NO may also potentiate progesterone mediated smooth muscle relaxation during pregnancy (Weiner et al. 1994, Chwalisz et al. 1996).
In our study, we observed a reduction in the percentage of pregnancy by the administration of a non-specific inhibitor of NOS, L-NAME $(22 \%$ at $4 \mathrm{mg}, 44 \%$ at $6 \mathrm{mg}$, and $29 \%$ at $8 \mathrm{mg}$ per $\mathrm{kg}$ body weight doses), as well as, a selective but not very specific inhibitor of iNOS, aminoguanidine (AG, 25\%) (Joly et al. 1994) as compared with control treated $(71 \%)$ animals. Although these differences are statistically not significant, these changes are note worthy. In fact, a proportion test analysis of the present set of data for different groups following 1000 replicate bootstrapping (Efron et al. 1996) reveals a very high level of significance $(P<0.001)$ in inhibition of pregnancy as the posterior probability of peri-implantation stage administration of NOS inhibitors. The observed decrease in the rate of successful pregnancy in the present study when viewed with a background, and an increasing bulk, of evidence suggesting a potential involvement of $\mathrm{NO}$ in the cytokine network (Schwentker et al. 2002), in the regulation of gene expression through modulation of transcription factors (Sen \& Packer 1996) and as a common downstream pathway for protein kinase C (PKC) and tyrosine kinases (Xuan et al. 1999) indeed supports the notion that timed inhibition of NOS activity during peri-implantation stage is likely to result in an interception in the establishment of pregnancy.

In the present study, the dose-response of L-NAME tested at higher doses of $6 \mathrm{mg}$ and $8 \mathrm{mg}$ per animal failed to increase the contraceptive efficacy of the drug. While the cause-effect relationship is only speculative at this point in time, it appears from our study with the monkey model that local administration of NOS inhibitor for targeted anti-implantation strategy in the primate results in a complex scenario. The pharmacokinetics of NOS inhibitor bioavailability at the local tissue bed in the given experimental model is not known, but the relatively low $\mathrm{PO}_{2}$ values around the time of blastocyst implantation and in the placenta during the first trimester of pregnancy (Yedwab et al. 1976, Rodesch et al. 1992, Graham et al. 2000) may function to modulate $\mathrm{NO}$ bioavailability. It is known that low ambient $\mathrm{pO}_{2}$, through enhanced binding to oxygenated hemoglobin, participates in physiological microvascular regulation, and hypoxemia enhances NO concentration while hyperoxemia results in accelerated NO removal (Heyman et al. 1999). We did not observe any marked change either in systemic blood pressure (Takiuti et al. 1999) or in sleep cycle pattern (Sippel et al. 1999) or on food intake pattern (Vozzo et al. 1999) in animals during the period of vaginal administration of NOS inhibitor (data not shown). We believe that locally administered NOS inhibitor was operative at the local level based on the fact that all the babies in the NOS inhibitor treated groups had significantly $(P<0.05)$ lower body weights as compared with babies from pregnant females in the control group and in our monkey colony in general. It is thus possible that local treatment with NOS inhibitors affect the NO system in fetal and maternal compartments resulting in retardation of embryonic growth without 
affecting ovarian function as no change in the levels of ovarian steroidal hormones was observed in NOS inhibitor treated animals. The embryotropic and anti-apoptotic actions of $\mathrm{NO}$ are now well documented in several biological models (Gouge et al. 1998, Dash et al. 2003, Teodoro \& O'Farell 2003, Tranguch et al. 2003).

Collectively, it appears from the present study that there exists a spatio-temporal pattern of NOS-expression in a cell-type specific manner in the embryo and maternal endometrium during implantation and placentation, and that NO plays an important role in the process of successful establishment of pregnancy in the rhesus monkey.

\section{Acknowledgements}

The study was funded by a World Health Organization Rockefeller Foundation project on Initiatives in Implantation Research awarded to DG and JS. We thank the Special Programme of Research, Development and Research Training in Human Reproduction for providing us with the reagents for oestradiol-17 $\beta$ and progesterone RIA from the $\mathrm{WHO}$ Matched Reagents Programme. The authors are thankful to Dr Rajvir Singh of the Department of Biostatistics, AIIMS for performing bootstrap statistics.

\section{References}

Ahmed A, Dunk C, Kniss D \& Wilkes M 1997 Role of VEGF receptor1 (Flt-1) in mediating calcium-dependent nitric oxide release and limiting DNA synthesis in human trophoblast cells. Laboratory Investigation 76 779-791.

Al-Hijji J, Andolf E, Laurini R \& Batra S 2003 Nitric oxide synthase activity in human trophoblast, term placenta and pregnant myometrium. Reproductive Biology and Endocrinology 151.

Ariel I, Hochberg A \& Shochina M 1998 Endothelial nitric oxide synthase immunoreactivity in early gestation and in trophoblastic disease. Journal of Clinical Pathology 51 427-431.

Battaglia C, Ciotti P, Notarangelo L, Fratto R, Facchinetti F \& de Aloysio D 2003 Embryonic production of nitric oxide and its role in implantation: a pilot study. Journal of Assisted Reproduction and Genetics 20 449-454.

Berdeaux A 1993 Nitric oxide: an ubiquitous messenger. Fundamental of Clinical Pharmacology 7 401-411.

Belensky SN, Robbins RA \& Rubinstein I 1993 Nitric oxide synthase inhibitors attenuate human monocyte chemotaxis in vitro. Journal of Leukocyte Biology 53 498-503.

Campa JS, Poston R \& Poston L 1998 Nitric oxide synthase (eNOS) is localized to the vascular endothelium of myometrium from pregnant women at term. Journal of Physiology $\mathbf{5 0 7} 69$.

Cha MS, Lee MJ, Je GH \& Kwak JY 2001 Endogenous production of nitric oxide by vascular endothelial growth factor down-regulates proliferation of choriocarcinoma cells. Biochemical and Biophysical Research Communications 282 1061-1066.

Chen HW, Jiang WS \& Tzeng CR 2001 Nitric oxide as a regulator in pre-implantation embryo development and apoptosis. Fertility and Sterility 75 1163-1171.

Chwalisz K \& Garfield R 2000 Role of nitric oxide in implantation and menstruation. Human Reproduction 15 Suppl 3 96-111.

Chwalisz K, Buhimschi I \& Garfield RE 1996 Role of nitric oxide in obstetrics. Prenatal and Neonatal Medicine $1292-328$.

Chwalisz K, Winterhager E, Hienel T \& Garfield R 1999 Synergistic role of nitric oxide and progesterone during the establishment of pregnancy in rats. Human Reproduction 14 542-552.
Conrad KP, Vill M, McGuire PG, Dail WG \& Davis AK 1993 Expression of nitric oxide synthase by syncytiotrophoblast in human placental villi. FASEB Journal 7 1269-1276.

Cotter G, Kaluski E, Milo O, Blatt A, Salah A, Hendler A, Krakover R, Golick A \& Vered Z 2003 L-NAME (a NO synthase inhibitor) in the treatment of refractory cardiogenic shock: a prospective randomized study. European Heart Journal 24 1287-1295.

Dash PR, Cartwright JE, Baker PN, Johnstone AP \& Whitley GS 2003 Nitric oxide protects human extravillous trophoblast cells from apoptosis by a cyclic GMP-dependent mechanism and independently of caspase 3 nitrosylation. Experimental Cell Research 287 $314-324$.

Dembinska-Kiec A, Zmuda A, Marcinkiewicz J, Sinzinger H \& Gryglewski RJ 1991 Influence of NO-donor (SIN-1) on functions of inflammatory cells. Agents and Actions 32 37-40.

Dhara S, Lalitkumar PGL, Sengupta J \& Ghosh D 2001 Immunohistochemical localization of insulin-like growth factors I and II at the primary implantation site in the Rhesus monkey. Molecular Human Reproduction 7 365-371.

Dhawan L, Ghosh D, Lalit kumar PGL, Sharma DN, Lasley B, Overstreet JW \& Sengupta J 2000 Anti-nidatory effect of vaginally administered $\left(\mathrm{Ala}^{8,13,18}\right)$ - magainin II amide in the rhesus monkey. Contraception 62 39-43.

Dong YL, Gangula PRR \& Yallampalli C 1996 Nitric oxide isoforms in the uterus: differential regulation during pregnancy and labour. Journal of Reproduction and Fertility 107 249-254.

Efron B, Halloran E \& Holmes S 1996 Bootstrap confidence levels. PNAS 93 7085-7090.

Enders AC \& King BF 1991 Early stages of trophoblastic invasion of the maternal vascular system during implantation in the macaque and baboon. American Journal of Anatomy 192 329-346.

Franchi A, Motta A, Farina M, Rivero ML, Ogando D \& Gimeno MF 1998 Effects of IL- $1 \alpha$ on prostaglandin synthesis of oestrogenized rat uterus is mediated by nitric oxide. Prostaglandins, Leukotrienes, and Essential Fatty Acids 58 413-416.

Gagioti S, Scavone C \& Bevilacqua E 2000 Participation of the mouse implanting trophoblast in nitric oxide production during pregnancy. Biology of Reproduction 62 260-268.

Ghosh D \& Sengupta J 1991 Heterologous embryo transfer in the rhesus monkey: an experimental primate model for the study of implantation. Medical Science Research 19 155-156.

Ghosh D \& Sengupta J 1993 Anti-nidatory effect of a single early post-ovulatory administration of mifepristone (RU486) in the rhesus monkey. Human Reproduction 8 552-558.

Ghosh D \& Sengupta J 2004a Target oriented anti-implantation approaches for pregnancy interception: Experiences in the rhesus monkey model. Contraception 71 294-301.

Ghosh D \& Sengupta J 2004b Endocrine and paracrine correlates of endometrial receptivity to blastocyst implantation in the human. Indian Journal of Physiology and Pharmacology 48 6-30.

Ghosh D, De P \& Sengupta J 1994 Luteal phase ovarian oestrogen is not essential for implantation and maintenance of pregnancy from surrogate embryo transfer in the rhesus monkey. Human Reproduction 9 629-637.

Ghosh D, Stewart DR, Nayak NR, Lasley BL, Overstreet JW, Hendrickx AG \& Sengupta J 1997 Serum concentration of estradiol$17 \beta$, progesterone, relaxin and chorionic gonadotrophin during blastocyst implantation in natural pregnancy and in embryo transfer cycle in the rhesus monkey. Human Reproduction 12 914-920.

Ghosh D, Dhara S, Kumar A \& Sengupta J 1999 Immunohistochemical localization of receptor for progesterone and estradiol- $17 \beta$ in the implantation site of the rhesus monkey. Human Reproduction 14 505-514.

Ghosh D, Lalitkumar PGL, Wong VJ, Hendrickx AG \& Sengupta J 2000a Pre-implantation embryo morphology following early luteal phase anti-nidatory treatment with mifepristone (RU486) in the rhesus monkey. Human Reproduction 15 180-188.

Ghosh D, Sharkey AM, Charnock-Jones DS, Dhawan L, Dhara S, Smith SK \& Sengupta J 2000b Expression of vascular endothelial 
growth factor (VEGF) and placental growth factor (PIGF) in conceptus and endometrium during implantation in the rhesus monkey. Molecular Human Reproduction 6 935-941.

Ghosh D, Bell SC \& Sengupta J 2004 Immunohistological localization of insulin-like growth factor binding protein-1 in primary implantation sites and trauma-induced deciduomal tissues of the rhesus monkey. Placenta 25 197-207.

Gouge RC, Marshburn P, Gordon BE, Nunley W \& Huet-Hudson YM 1998 Nitric oxide as a regulator of embryonic development. Biology of Reproduction 58 875-879.

Graham CH, Postovit LM, Park H, Canning MT \& Fitzpatrick TE 2000 Role of oxygen in the regulation of trophoblast gene expression and invasion. Placenta 21 443-450.

Hambartsoumian E, Srivastava RK \& Seibel MM 2001 Differential expression and regulation of inducible nitric oxide synthase (iNOS) mRNA in human trophoblast cells in vitro. American Journal of Reproductive Immunology 45 78-85.

Heyman SN, Goldfarb D, Darmon D \& Brezis M 1999 Tissue oxygenation modifies nitric oxide bioavailability. Microcirculation 6 199-203.

Hornung D, Lebovic DI, Shifren JL, Vigne JL \& Taylor RN 1998 Vectorial secretion of vascular endothelial growth factor by polarized human endometrial epithelial cells. Fertility and Sterility 69 909-915.

Joly GA, Ayres M, Chelly F \& Kilbourn RG 1994 Effects of $N^{G}$-methylL-arginine, $\mathrm{N}^{\mathrm{G}}$-nitro-L-arginine, and aminoguanidine on constitutive and inducible nitric oxide synthase in rat aorta. Biochemical Biophysical Research Communications 199 147-154.

Khorram O, Garthwaite M \& Magness RR 1999 Endometrial and myometrial expression of nitric oxide synthase isoforms in preand postmenopausal women. Journal of Clinical Endocrinology and Metabolism $842226-2232$.

Kimura T, Yoshida Y \& Toda N 1992 Mechanisms of relaxation induced by prostaglandins in isolated canine uterine arteries. American Journal of Obstetrics and Gynecology 167 1409-1416.

Lopez JM \& Gonzalez A 2002 Ontogeny of NADH diaphorase/nitric oxide synthase reactivity in the brain of Xenopus laevis. Journal of Comparative Neurology 445 59-77.

Lyall F, Bulmer JN, Kelly H, Duffie E \& Robson SC 1999 Human trophoblast invasion and spiral artery transformation: the role of nitric oxide. American Journal of Pathology 154 1105-1114.

Martin D \& Conrad KP 2000 Expression of endothetial nitric oxide synthase by extravillous trophoblast cells in the human placenta. Placenta 21 23-31.

Moncada S, Palmer RMJ \& Higgs EA 1991 Nitric oxide: physiology, pathophysiology and pharmacology. Pharmacological Reviews 43 109-142.

Mordenti J 1986 Man versus beast: pharmacokinetic scaling in mammals. Journal of Pharmacological Sciences 75 1028-1040.

Morgan DR, Silke B, Dixon LJ, Allen PB, Hanratty CG \& McVeigh GE 2003 Central and peripheral haemodynamic effects of L-NAME infusion in healthy volunteers. European Journal of Clinical Pharmacology 59 195-199.

Myatt L, Brockman DE, Eis ALW \& Pollock JS 1993 Immunohistochemical localization of nitric oxide synthase in the human placenta. Placenta 14 487-495.

Nanaev A, Chwalisz K, Frank HG, Kohnen G, Hartung H \& Kaufmann P 1995 Physiological dilatation of uteroplacental arteries in the guinea pig depends on nitric oxide synthase activity of extravillous trophoblast. Cell Tissue Research 282 407-421.

Natuzzi EC, Ursell PC, Harrison M, Buscher C \& Reimer RK 1993 Nitric oxide synthase activity in the pregnant uterus decreases at parturition. Biochemical and Biophysical Research Communications 194 1-8.

Nishikimi A, Matsukawa T, Hoshino K, Ikeda S, Kira Y, Sato EF, Inoue M \& Yamada M 2001 Localization of nitric oxide synthase activity in unfertilized oocytes and fertilized embryos during pre-implantation development in mice. Reproduction 122 957-963.
Noiri E, Peresleni T, Srivastava N, Weber P, Bahou WF, Peunova N \& Goligorsky MS 1996 Nitric oxide is necessary for a switch from stationary to locomoting phenotype in epithelial cells. American Journal of Physiology 270 C794-C802.

Novaro V, Colman-Lerner A, Ortega FV, Jawerbaum A, Paz D, Lo Nostro F, Pustovrh C, Gimeno MF \& Gonzalez E 2001 Regulation of metalloproteinases by nitric oxide in human trophoblast cells in culture. Reproduction Fertility and Development 13 411-420.

Novaro V, Pustovrh C, Colman-Lerner A, Radisky D, Lo Nostro F, Paz D, Jawerbaum A \& Gonzalez E 2002 Nitric oxide induces gelatinase A (matrix metalloproteinase 2) during rat embryo implantation. Fertility and Sterility 78 1278-1287.

Okada Y, Asahina T, Kobayashi T, Goto J \& Terao T 2001 Studies on the mechanism of edematous changes at the endometrial stroma for implantation. Seminars in Thrombosis and Hemostasis $2767-77$.

Ota H, Igarashi S, Oyama N, Suzuki Y \& Tanaka T 1999 Optimum levels of nitric oxide are crucial for implantation in mice. Reproduction Fertility and Development 11 183-188.

Purcell TL, Given R, Chwalisz K \& Garfield RE 1999 Nitric oxide synthase distribution during implantation in the mouse. Molecular Human Reproduction 5 467-478.

Radomski MW 1995 Nitric oxide - biological mediator, modulator and effector molecule. Annals of Medicine 27 321-329.

Radomski MW, Palmer RMJ \& Moncada S 1987 The role of nitric oxide and CGMP in platelet adhesion to vascular endothelium. Biochemical and Biophysical Research Communications 148 $1482-1489$.

Ramsay B, Sooranna SR \& Johnson MR 1996 Nitric oxide synthase activates in human myometrium and villous trophoblast throughout pregnancy. Obstetrics and Gynecology 87 249-253.

Rodesch F, Simon P \& Donner C \& Jauniaux E 1992 Oxygen measurements in endometrial and trophoblastic tissue during early pregnancy. Obstetrics and Gynecology 80 283-285.

Rogers PA, Abberton KM \& Susil B 1992 Endothelial cell migratory signal produced by human endometrium during the menstrual cycle. Human Reproduction 7 1061-1066.

Sanyal M, Nag TC \& Das C 2000 Localization of nitric oxide synthase in human trophoblast cells: role of nitric oxide in trophoblast proliferation and differentiation. American Journal of Reproductive Immunology 43 70-77.

Schmidt HH, Gagne GD, Nakane M, Pollock JS, Miller MF \& Murad F 1992 Mapping of neuronal nitric oxide synthase in the rat suggests frequent co-localization with NADPH diaphorase but not with soluble guanylyl cyclase, and novel paraneural functions for nitrinergic signal transduction. The Journal of Histochemistry and Cytochemistry 40 1439-1456.

Schwentker A, Vodovotz Y, Weller R \& Billiar TR 2002 Nitric oxide and wound repair: role of cytokines. Nitric Oxide 7 1-10.

Sen CK \& Packer L 1996 Antioxidant and redox regulation of gene transcription. FASEB Journal 10 709-720.

Sengupta J, Dhawan L \& Ghosh D 2003 Immunohistochemical localization of leukemia inhibitory factor, interleukins 1 and 6 at the primary implantation site in the rhesus monkey. Cytokine $\mathbf{2 4}$ 277-285.

Sippel JM, Giraud GD \& Holden WE 1999 Nasal administration of the nitric oxide synthase inhibitor L-NAME induces daytime somnolence. Sleep 22 786-788.

Sladek SM, Magness RR \& Conrad KP 1997 Nitric oxide and pregnancy. American Journal of Physiology 272 R441-R463.

Sooranna SR, Morris NH \& Steer PJ 1995 Placental nitric oxide metabolism. Reproduction Fertility and Development 7 $1525-1531$.

Taguchi M, Alfer J, Chwalisz K, Beier HM \& Classen-Linke I 2000 Endothelial nitric oxide synthase is differentially expressed in human endometrial vessels during the menstrual cycle. Molecular Human Reproduction 6 185-190.

Takiuti NH, Carvalho MH, Kahhale S, Nigro D, Barbeiro HV \& Zugaib M 1999 The effect of chronic nitric oxide inhibition on 
vascular reactivity and blood pressure in pregnancy in pregnant rats. Sao Paulo Medical Journal 117 197-204.

Tamura T, Nakanishi T, Kimura Y, Hattori T, Sasaki K, Norimatsu H, Takahashi K \& Takigawa M 1996 Nitric oxide mediates interleukin-1 induced matrix degradation and basic fibroblast growth factor release in cultured rabbit articular chondrocytes: a possible mechanism of pathological neovascularization in arthritis. Endocrinology 137 3729-3737.

Telfer JF, Lyall F, Norman JE \& Cameron IT 1995 Identification of nitric oxide synthase in human uterus. Human Reproduction 10 19-23.

Telfer JF, Irvine GA, Kohnen G, Campbell S \& Cameron IT 1997 Expression of endothelial and inducible nitric oxide synthase in nonpregnant and decidualized human endometrium. Molecular Human Reproduction 3 69-75.

Teodoro RO \& O'Farell PH 2003 Nitric oxide-induced suspended animation promotes survival during hypoxia. The EMBO Journal 22 580-587.

Tranguch S, Steuerwald N \& Huet-Hudson YM 2003 Nitric oxide synthase production and nitric oxide regulation of pre-implantation embryo development. Biology of Reproduction 68 1538-1544.

Tseng L, Zhang J, Peresleni TY \& Goligorsky MS 1996 Cyclic expression of endothelial nitric oxide synthase mRNA in the epithelial glands of human endometrium. Journal of the Society for Gynecologic Investigation 3 33-38.

Van Buren GA, Yang DA \& Clark KE 1992 Estrogen induced uterine vasodilatation is antagonized by L-arginine methyl ester, an inhibitor of nitric oxide synthesis. American Journal of Obstetrics and Gynecology 163 828-833.

Vozzo R, Wittert GA, Horowitz M, Morley JE \& Chapman IM 1999 Effect of nitric oxide synthase inhibitors on short-term appetite and food intake in human. American Journal of Physiology 276 R1562-R1568.

Weiner CP, Knowles RG \& Moncada S 1994 Induction of nitric oxide synthases early in pregnancy. American Journal of Obstetrics and Gynecology 171 838-843.

Xuan YT, Tabg XL, Banerjee S, Takano H, Li RC, Han H, Qiu Y, Li JJ \& Boll R 1999 Nuclear factor-kappaB plays an essential role in the late phase of ischemic preconditioning in conscious rabbits. Circulation Research 84 1095-1109.

Yallampalli C, Byam-Smith M, Nelson SO \& Garfield RE 1994 Nitric oxide inhibits uterine contractility during pregnancy but not during delivery. Endocrinology 133 1899-1902.

Yedwab GA, Paz G, Homonnai TZ, David MP \& Kraicer PF 1976 The temperature, $\mathrm{pH}$ and partial pressure oxygen in the cervix and uterus of women and uterus of rats during the cycle. Fertility and Sterility 27 304-309.

Zar JH 1999 In Biostatistical Analysis, 4th edn., pp 177-554. New Jersey: Prentice Hall.

Ziche M, Morbidelli L, Masini E, Amerini S, Granger HJ, Maggi CA, Geppetti P \& Ledda F 1994 Nitric oxide mediates angiogenesis in vivo and endothelial cell growth and migration in vitro promoted by substance P. Journal of Clinical Investigation 94 2036-2044.

Received 13 October 2004

First decision 13 December 2004

Revised manuscript received 21 April 2005

Accepted 26 May 2005 